\title{
Examining Land Use Changes to Evaluate the Effects of Land Management in a Complex, Dynamic Landscape
}

\author{
Amanda K. Martin $\mathbb{D}^{1} \cdot$ Karen V. Root $\mathbb{D}^{1}$ \\ Received: 16 January 2020 / Accepted: 9 June 2020 / Published online: 22 June 2020 \\ (c) The Author(s) 2020
}

\begin{abstract}
Anthropogenic alterations to landscapes have increased as the human population continues to rise, leading to detrimental changes in natural habitats. Ecological restoration assists in recovery by altering habitats to improve conditions and foster biodiversity. We examined land cover changes over time within a complex, dynamic region in the Midwest to assess the long-term effects of conservation. We used Landsat 8 bands for a 15-class land cover map of Oak Openings Region using supervised classification. We validated our map and achieved an overall accuracy of $71.2 \%$ from correctly classified points out of total visited points. Change over 10 years, from 2006 to 2016, was explored by comparing class statistics from FRAGSTATS between our map and original land cover map. We found that natural land, i.e., forest and early successional, covered $33 \%$, with $10 \%$ permanently protected, while human-modified land, i.e., agricultural and developed, covered $67 \%$ of the region. Over 10 years, natural classes increased, and cultural classes decreased by $5.8 \%$. There were decreases for the three forest communities and increases for the two early successional communities. These changes are likely the result of natural recovery and disturbance, and conservation efforts by the Green Ribbon Initiative. Changes in habitat also came with distribution changes, e.g., increased fragmentation for some classes, which was readily visible. Our useful method measured functionality by emphasizing changes in composition and configuration. Our approach provides a tool for assessing cumulative regional-scale effects from site-level management and conservation. This large-scale view for conservation is needed to effectively mitigate future changes.
\end{abstract}

Keywords Conservation $\cdot$ Land cover change $\cdot$ Oak Openings Region $\cdot$ Urbanization $\cdot$ Vegetation classification

\section{Introduction}

Growing anthropogenic pressures continue to intensify and affect natural and semi-natural ecosystems. As these pressures increase, there is a greater drive to quantify land-use land cover (LULC) changes. Since LULC is one of the most important variables that affects global ecosystems (e.g., Lovell and Johnston 2009; Srivastava et al. 2012; Cordell et al. 2016). There are many alterations in modern landscape structure, many of which are expected to be fairly

Supplementary information The online version of this article (https:// doi.org/10.1007/s00267-020-01316-2) contains supplementary material, which is available to authorized users.

Amanda K. Martin

amandkm@bgsu.edu

1 Department of Biological Sciences, Bowling Green State University, Bowling Green, OH 43403, USA permanent with continued urbanization. However, these changes without some level of intervention, such as land acquisition and then restoration, can lead to the loss of critical ecosystem functions (O'Farrell and Anderson 2010). Such as local extinctions of plants and their associated animals, as seen in converting temperate grasslands into croplands or forests into grasslands (Sala et al. 2000). These abrupt environmental changes occur at different scales (e.g., local, regional, and global) and have been increasing over time as a result of both natural and anthropogenic processes. However, many of these changes are especially driven by urbanization which continually fragment and reduce natural habitats. Urbanization and human activities have expedited ecosystem(s) suffering from degradation, damage, and/or destruction, which has led to a larger focus on ecological restoration (Sala et al. 2000; Matzek et al. 2017). Many local organizations that focus on providing stronger support for restoration and conservation efforts require different tools that foster an assessment of change from the past, current, and future potential, especially for these dynamic 
landscapes. In particular, land managers need a way to assess the effects of their efforts across scales (temporal and spatial), or a way to put local scale management (i.e., individual parcels) into larger-scale conservation targets across landscapes (e.g., watersheds).

In a region where there are remnant natural habitat patches in a matrix of human-modified habitat types, e.g., agriculture, residential, there is a need to actively manage threats such as invasive species, fire suppression, water diversion, and human disturbance. An example of one of these dynamic yet diverse landscapes is Oak Openings Region within southeastern Michigan and northwestern Ohio, USA, described in more detail below. Large conservation efforts have focused on examining the changes within this region (e.g., Schetter et al. 2013; Abella et al. 2017), and there have been significant alterations as a result of anthropogenic activities (e.g., development, restoration), natural disturbance (e.g., tornado) and invasive species (e.g., emerald ash borer, Agrillus planipennis, Fairmaire). Traditional approaches towards ecological restoration include the community and ecosystem approach. For an example, targeted management practices focus on a few select species, such as the listed Karner Blue Butterfly (Lycaeides milissa samuelis, Nabokov), or on a particular ecosystem, e.g., oak savanna, and manage for those targets using prescribed fire, mowing, etc. (Pickens and Root 2008; Pickens and Root 2009).

In Oak Openings Region there are several globally imperiled ecosystems, including oak savanna, which are the focus of conservation efforts (Abella et al. 2007; Schetter et al. 2013). The Green Ribbon Initiative (GRI) is a local conservation group that brought together multiple agencies in a partnership to protect the Oak Openings Region's natural beauty and biological diversity (https://oa kopenings.org). The GRI mission is to enhance and restore critical natural areas and has focused on the conservation of five target ecosystems: upland savanna/prairie, wet prairie, upland deciduous forest, floodplain forest, and flatwoods/swamp forest (Gardner 2016). These ecosystems are especially vulnerable because of threats from invasive species such as emerald ash borer for forest (Kashian and Witter 2011; Herms and McCullough 2014), woody encroachment (Eldridge et al. 2011) for temperate grassland, altered fire regimes for oak savanna (Peterson and Reich 2001), and channel drainage for wet prairie (Wijayarathne 2015). Ecosystem-based management, such as targeting the five major communities in Oak Openings Region (Supplement Figure 1), aims to better protect dynamic and functional habitats that support a diverse array of species. In addition, land managers can incorporate target species associated with specific ecosystems in order to facilitate conservation. In this region, active management is used to combat current threats, as well as continued land acquisition, and restoration to help restore functionality.

Spatial tools are invaluable in guiding the assessment of restoration efforts, evaluating management options, identifying conservation priorities, and quantifying threats across various scales (Cordell et al. 2016). The landscape ecology approach emphasizes structure, e.g., spatial heterogeneity, function, connectivity, and can potentially help identify the aggregate effects of site scale management across a region (Bell et al. 1997; Ehrenfeld and Toth 1997; Lovell and Johnston 2009; O'Farrell and Anderson 2010; Cordell et al. 2016). LULC changes have been monitored by traditional field inventories and surveys, but satellite remote sensing provides an accessible and efficient method of acquiring information on temporal and spatial trends (Yuan et al. 2005; Lovell and Johnston 2009). In terms of cost, time, and area coverage, quantifying these changes from Landsat data can be more effective than field surveys (El Baroudy and Moghanm 2014) and potentially provide a broader perspective on functionality (Lovell and Johnston 2009).

In addition to measuring LULC changes, integrating landscape-pattern metrics from FRAGSTATS with Geographic Information System (GIS) mapping can enhance landscape analysis by quantifying structural changes within ecosystems at various spatial scales (Lovell and Johnston 2009). Changes in both composition and configuration are invaluable for restoration efforts especially for heterogeneous landscapes that vary in the types and proportions of different land covers and how they are arranged on the landscape. The landscape is defined by this heterogeneity and has varying impacts on biodiversity (Fahrig 2003; Fahrig et al. 2011; Tscharntke et al. 2012). These are examined through the lens of area, density, edge, shape, proximity, interspersion, connectivity and diversity metrics, which include parameters such as number of patches, perimeter-area ratio, patch richness, etc. (Torbick et al. 2006; Driezen et al. 2007; Schetter et al. 2013; Herse et al. 2018). These metrics, specifically landscape and class-level, are reliable for assessing natural and/or anthropogenic LULC changes that disrupt abiotic or biotic landscape structure including management activities (Gottgens et al. 1998; Lopez et al. 2002; Houlahan and Findlay 2004; Johnston and Rejmánková 2005). In addition, class-level spatial patterns are important for species conservation (Murphy and Noon 1992; Villard et al. 1999) as a result of their high correlations with various ecological processes. For an example, patch cohesion captures a biologically relevant aspect of landscape structure (i.e., habitat connectivity) by evaluating multiple landscape structural properties on a continuous scale. In addition, it can be used to estimate partial habitat suitability values for multiple species dependent on similar habitat, but with varying abilities and spatial scale (Wilson 2007). 
We examined landscape changes in terms of composition and configuration over a 10-year period, from 2006 to 2016, for the highly heterogeneous Oak Openings Region in Northwest Ohio and Southeast Michigan. We wanted to highlight where and how much land cover changed to better aid local conservation efforts towards prioritization, land acquisition, restoration, and management. In addition, we established a generalizable model for similar restoration efforts for other dynamic landscapes. We anticipated that we should see improvement in the extent of the five focal ecosystems within protected areas as a result of targeted management activities. We also expected that humanmodified land cover types would increase with expanding urbanization outside of protected lands. Our objectives were to: (1) create an updated land cover map; (2) compare changes in land cover over time; and (3) provide a tool to evaluate conservation efforts including acquisition, restoration, and land management. We utilized the original Northwest Ohio land cover map based on 2006 data (Schetter and Root 2011) to compare the relative changes over time with the updated Northwest Ohio land cover map based on 2016 data; however, we emphasized the five focal communities targeted for restoration and conservation. We tested the following predictions as a result of the restoration efforts of local land managers. We first predicted that natural areas (especially for the five major communities of concern) within protected lands will have increased over time because of restoration and land acquisition efforts. We then predicted that number of patches and edge density will decrease, while average patch area and the largest patch size will increase over time as a result of efforts towards increasing connectivity between protected areas. Our study is unique through the incorporation of both composition and configuration metrics, i.e., total area, connectivity, to measure changes in functionality over time.

\section{Methods}

\section{Study Area}

The full extent of Oak Openings Region, mapped area of 194,000 ha, ranges from Northwest Ohio including Henry, Fulton and Lucas counties to Southeast Michigan including Monroe, Wayne, Washtenaw, Wayne, and Oakland counties $\left(41^{\circ} 27^{\prime}\right.$ to $42^{\circ} 10^{\prime} \mathrm{N} ; 83^{\circ} 51^{\prime}$ to $\left.83^{\circ} 32^{\prime} \mathrm{W}\right)$. Although this landscape is highly fragmented, it contains five globally rare communities (Brewer and Vankat 2004) that have great conservation value as a result of the amount of rare species and unique habitats. For historic and detailed description of land cover classes refer to Schetter and Root (2011). It is a highly heterogeneous landscape that lies within anthropogenic lands (e.g., agriculture, residential, urban), yet it remains a local biodiversity hotspot for state endangered, threatened, potentially threatened species (e.g., Sweet-fern (Comptonia peregrine, Coult), Showy Lady's-slipper (Cypripedium reginae, Walter), Grass-pink orchid (Calopogon tuberosus, Britton, Sterns, and Poggenb), Bluntleaved milkweed (Asclepias amplexicaulis, Sm.)). Several endangered or threatened species, such as the Karner Blue Butterfly and northern long-eared bat (Myotis septentrionalis, Trouessart), depend on the rare natural communities found in this region. Despite the small size (Ohio portion 47,800 ha, Michigan portion 146,200 ha), Oak Openings Region contains nearly a third of Ohio's rare plants and animals (Schetter et al. 2013).

\section{Landsat 8 Image Selection}

We acquired three multi-season images from the United States Geological Survey (USGS) Earth Explorer (USGS 2017) for the early, mid, and late growing season. The three images were from Landsat 8 (Tier 1) on 16 April 2016, 19 June 2016, and 9 October 2016 for Path 20, Row 31, which contained our entire study area. Multi-seasonal imagery was especially useful for examining dynamic vegetation patch patterns and improved classification for forest cover (Gudex-Cross et al. 2017; Clark et al. 2018; Higginbottom et al. 2018), grassland (Poulin et al. 2010; Wang et al. 2010; Dusseux et al. 2014), land use/land cover changes (Löw et al. 2015; Nitze et al. 2015; Zhao et al. 2016) and more (Liu et al. 2019). We required each image: (1) occurred within a narrow 6-month timeframe, (2) featured $0 \%$ cloud cover within our study area, and (3) contained Level-1 Precision Terrain (L1T) images. We downloaded all images in GeoTif image format and projected to Universal Transverse Mercator coordinates (UTM Datum WGS84). The Landsat 8 images were multispectral; however, the 1Coastal Aerosol, 8-Panchromatic, and 9-Cirrus bands were excluded in our final classification to more accurately compare to Schetter and Root (2011) classification, hereafter referred to as the original map. The original map used three multi-seasonal Landsat-5 TM scenes acquired in 2006.

\section{Training Site Selection}

We used the original Ohio training sites from Schetter and Root (2011) 2006 land cover classification and included novel training sites, these are sites that were not used in the 2006 land cover classification, within Ohio and Michigan collected by The Nature Conservancy. The original Ohio training sites were revisited to confirm land cover type after the 10-year period. We delineated training sites with enough training pixels for a supervised classification within ArcGIS 10.2 (Environmental Systems Research Institute, Redlands, California) across Oak Openings Region. We used 27 bands 
(9 per image), each with $30 \mathrm{~m}$ pixel resolution that required a minimum of 28 pixels per land cover class $(n+1$ pixels required per class, where $n$ is the number of used spectral bands). We used 132 training sites for 14 classes (average of 9 training sites per class).

\section{Supervised Image Classification}

We performed a supervised classification for 14-land cover types that matched the original 2006 land cover classification using maximum likelihood classification model in ArcGIS 10.2. Cropland was difficult to classify because of seasonal changes in planted crops' type and phenology. Therefore, we applied a cropland "mask" (USDA 2016) to the 14-land cover classification and produced the final image (as in Schetter and Root 2011). After we applied the mask, we clipped the 15-class image for Oak Openings Region (Gardner 2016) and then clipped the 15-class image to the historic extent of Oak Openings Region in Northwest Ohio for comparison to the original map (Brewer and Vankat 2004). The 15 landcover classes are listed in Table 1 with photographs for several major land cover classes (Supplementary Fig. 2). These land covers are distinguished by the class descriptions defined by Schetter and Root (2011). Briefly defined for some of the major land covers: swamp forest contains closed-canopy deciduous swamps/ flatwoods that are semi-permanent to seasonal, whereas

Table 1 Oak Openings land cover classification system for the 15class, 7-class, and 5 target ecosystems

\begin{tabular}{lll}
\hline 15 land cover classes & $\begin{array}{l}7 \text { land cover } \\
\text { classes }\end{array}$ & 5 target ecosystems \\
\hline Swamp forest (SF) & $\begin{array}{l}\text { Forest \& } \\
\text { woodland }\end{array}$ & Swamp forest \\
Floodplain Forest (FF) & & Floodplain forest \\
Upland Deciduous & Deciduous forest \\
forest (UD) & \\
Upland Coniferous & \\
forest (UC) & \\
Upland Savanna (US) & Savanna & Savanna/Prairie \\
$\begin{array}{l}\text { Wet Shrubland (WS) } \\
\text { Wet Prairies (WP) }\end{array}$ & $\begin{array}{l}\text { Shrubland } \\
\text { Prairie } \\
\text { Upland Prairie (UP) }\end{array}$ & Weadow Prairie \\
$\begin{array}{l}\text { Sand Barren (SB) } \\
\text { Eurasian Meadow (EM) }\end{array}$ & \\
$\begin{array}{l}\text { Water (PP) } \\
\text { Dense Urban (DU) }\end{array}$ & Water & Savanna/Prairie \\
Residential/Mixed (RM) & & \\
Turf/Pasture (TP) & Vacant & \\
Cropland (CR) & & \\
\hline
\end{tabular}

floodplain forests have closed to open canopy deciduous forest that are poor to moderately well drained. Wet shrublands have a well-developed herbaceous layer that is semi-permanent to seasonal on soils that are poorly drained. Upland savannas contain open canopy oak stands with welldrained soils and a developed herbaceous and shrub layer, dominated by warm-season grasses and forbs, whereas trees are nearly or completely absent within upland prairies and shrub layers are generally sparse or absent on these mesic to dry areas with warm-season grasses. Finally, wet prairies have nearly or entirely absent trees and shrubs and are semipermanent to seasonal on poorly drained soils.

\section{Accuracy Assessment}

We assessed the accuracy of the classification with a combination of field surveys and orthophotos. Ground truth points for field surveys were created in ArcGIS 10.2 and were at least $150 \mathrm{~m}$ apart within protected lands to ensure a reasonable sample distribution. Points were selected within areas that were readily accessible for which we visited 270 points. Travel time was minimized by evaluating four adjacent neighboring points from the selected point. We visually inspected ground truth points within major communities of concern (e.g., upland savanna, upland prairie, wet prairie, upland deciduous forest, floodplain forest, and swamp forest), and identified if the land cover class was accurately designated by the supervised classification. The point was considered correctly classified if within $5 \mathrm{~m}$ of the area at the point matched the updated map classification and was marked as incorrect if it did not match. In addition, we verified the classification using high resolution $(0.3 \mathrm{~m})$ color orthophotos acquired in 2017 (USGS 2017). We used orthophotos for distinguishable, identifiable land cover classes (e.g., cropland, dense urban, residential/mixed, water, and upland coniferous forest) across the study region. We followed the same methodology as the field surveys by evaluating the four adjacent neighboring points for a total of 230 points. We evaluated overall accuracy for all 15-land cover types and 7-level land cover (class descriptions in Schetter and Root 2011), see Table 1 for the list of each set. We compiled the assessment results in an error matrix.

\section{Regional Assessment}

We assessed land cover changes in Oak Openings Region for a 10-year period by comparing the updated map to the original map for three groups: a 15-level classification, a 7-level classification (defined in Schetter and Root 2011) and for the five major communities of concern, see Table 1 for the list for each set. The 15-land cover classes were combined to create the seven-level classes, which included forest and woodland (i.e., swamp forest, floodplain forest, upland 
deciduous forest, upland coniferous forest), savanna (i.e., upland savanna), shrubland (i.e., wet shrubland), prairie and meadow (i.e., wet prairie, upland prairie, sand barren, Eurasian meadow), water (i.e., perennial pond), built-up (i.e., dense urban, residential/mixed), and vacant (i.e., turf/pasture, cropland), Table 1 . In addition, we evaluated changes among protected and unprotected lands using a protected lands shapefile layer (Northwestern Ohio Park Inventory). Using FRAGSTATS 4.2.1 (McGarigal and Marks 1995) we examined landscape-pattern metrics by compiling per-class data on the total area, average class area, number of patches, and the largest patch index. We examined in FRAGSTATS 4.2.1 estimates of connectivity (i.e., patch cohesion index), dispersion (i.e., clumpy) and heterogeneity (i.e., patch richness) using a moving window neighborhood analysis with a $120 \mathrm{~m}$ by $120 \mathrm{~m}$ window. Landscape-pattern metrics were evaluated first for the seven-level class model and then for the five major communities of concern.

\section{Restoration within Oak Openings Preserve}

We examined restoration efforts through land cover change within Oak Openings Preserve over a 10-year period. We assumed that most of the changes that occurred during this period were linked to management actions, as this park is heavily managed. Targeted efforts have been removing and converting upland coniferous forest to early successional land cover among other interventions. We assessed these changes by compiling per-class data on the total area and number of patches delineated in FRAGSTATS 4.2.1.

\section{Results}

\section{Map Characteristics}

\section{5-class land cover}

The final updated 15-class land cover map was classified for the full extent of Oak Openings Region, which includes Northwest Ohio and Southeast Michigan (Fig. 1). For all other analyses, we only used the portion contained in Northwest Ohio for comparison of changes over time to Schetter and Root (2011), which did not include Michigan. We found that natural/seminatural land cover classes in the updated map increased to $33 \%$ of the region, while cultural land cover classes decreased to $67 \%$ of the total area. We found that the total area (i.e., eight classes), average patch area (i.e., 11 classes), the number of patches (i.e., seven classes), and the largest patch index (i.e., 10 classes) increased over time (Table 2). Upland prairie had the greatest increase in the total area of 2502 ha and increased

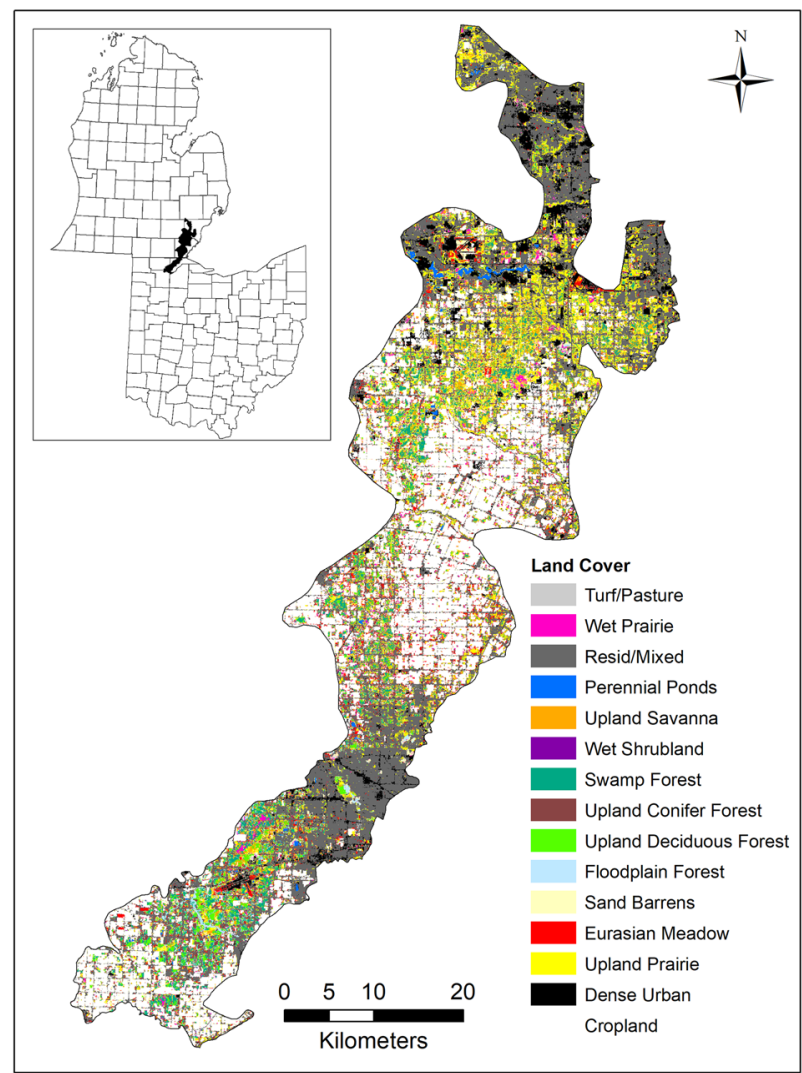

Fig. 1 Map of the 15-class updated land cover map of Oak Openings Region in Northwest Ohio and Southeast Michigan

by 4260 patches, while turf/pasture had the greatest decrease in the total area of 3102 ha and decreased by 7115 patches. Residential/mixed had the greatest increase in the average patch area of 2.6 ha and increased by $5 \%$ in the largest patch index, while cropland had the greatest decrease in the average patch area of 31.5 ha and decreased by $0.1 \%$ in the largest patch index.

\section{Seven-class land cover}

When we examined changes across our seven-level classes, we found that forest and woodland lost $5.4 \%$ of habitat, whereas prairie and meadow gained $10.9 \%$ of habitat. We additionally found that savanna and built-up increased, respectively, by 1.2 and $1.8 \%$, whereas vacant and shrubland decreased, respectively, by 7.6 and $0.4 \%$ (Table 2). In terms of structure, we found that vacant, forest and woodland, shrubland, and water decreased in total area over time, while prairie and meadow had the greatest increase followed by built-up and savanna. We found that vacant, builtup and forest and woodland lost more than 1000 patches, while prairie and meadow increased by 2332 patches (Table 2). Over the 10-year period, the average patch area increased for each of the seven-level classes. 
Table 2 Summary of land cover results using Total Area, Average (AVG) Patch Area, Number (\#) of Patches, and the Largest Patch Index (LPI) for the seven-level class system and five major communities of concern for the original (Schetter and Root 2011) and updated map within Oak Openings Region in Northwest Ohio

\begin{tabular}{|c|c|c|c|c|c|c|c|c|}
\hline \multirow[b]{2}{*}{ Class } & \multicolumn{2}{|c|}{ Total area (ha) } & \multicolumn{2}{|c|}{ AVG area (ha) } & \multicolumn{2}{|c|}{ \# Patches } & \multicolumn{2}{|c|}{ LPI (\%) } \\
\hline & 2006 & 2016 & 2006 & 2016 & 2006 & 2016 & 2006 & 2016 \\
\hline \multicolumn{9}{|l|}{ Natural/Seminatural } \\
\hline Forest and Woodland & 9734 & 7021 & 3.7 & 4.3 & 2634 & 1617 & 3.43 & 2.7 \\
\hline Swamp Forest & 1496 & 3205 & 0.4 & 1.4 & 3761 & 2235 & 0.09 & 0.2 \\
\hline Floodplain Forest & 4259 & 1503 & 0.7 & 0.5 & 6189 & 3129 & 0.41 & 0.4 \\
\hline Upland Deciduous Forest & 3073 & 1914 & 1.1 & 1.2 & 2937 & 1659 & 0.16 & 0.1 \\
\hline Upland Coniferous Forest & 907 & 400 & 0.8 & 1.2 & 1133 & 330 & 0.2 & 0.1 \\
\hline Savanna (Upland Savanna) & 370 & 959 & 0.2 & 0.4 & 1664 & 2408 & 0.05 & 0.1 \\
\hline Shrubland (Wet Shrubland) & 193 & 5 & 0.3 & 0.4 & 732 & 14 & 0.05 & 0.0 \\
\hline Prairie and Meadow & 2438 & 7679 & 0.5 & 1.0 & 5048 & 7380 & 0.14 & 0.5 \\
\hline Wet Prairie & 40 & 695 & 0.4 & 0.3 & 104 & 2400 & 0.02 & 0.1 \\
\hline Upland Prairie & 610 & 3112 & 0.2 & 0.4 & 2819 & 7079 & 0.04 & 0.1 \\
\hline Sand Barren & 359 & 2071 & 0.2 & 0.4 & 1946 & 5161 & 0.01 & 0.1 \\
\hline Eurasians Meadow & 1429 & 1802 & 0.4 & 0.4 & 3884 & 4622 & 0.09 & 0.1 \\
\hline Water (Perennial Pond) & 253 & 236 & 0.9 & 1.3 & 290 & 186 & 0.05 & 0.1 \\
\hline \multicolumn{9}{|l|}{ Cultural } \\
\hline Built-up & 18749 & 19669 & 4.2 & 7.3 & 4445 & 2699 & 28.1 & 33.2 \\
\hline Dense Urban & 1833 & 1908 & 1.1 & 0.9 & 1688 & 2057 & 0.33 & 0.4 \\
\hline Residential/Mixed & 16915 & 17761 & 3.5 & 6.1 & 4812 & 2905 & 24.3 & 29.3 \\
\hline Vacant & 16042 & 12189 & 3.3 & 16.9 & 4801 & 720 & 22 & 17.1 \\
\hline Turf/Pasture & 3141 & 39 & 0.4 & 0.6 & 7183 & 68 & 0.1 & 0.0 \\
\hline Cropland & 12901 & 12150 & 50.0 & 18.5 & 258 & 657 & 16.4 & 17.1 \\
\hline
\end{tabular}

Italic numbers represent increases over time

Fig. 2 Percentage of area for all natural/seminatural, all cultural land covers and for each of the five major communities of concern for the original (pattern) and updated (no pattern) land cover map in Oak Openings Region

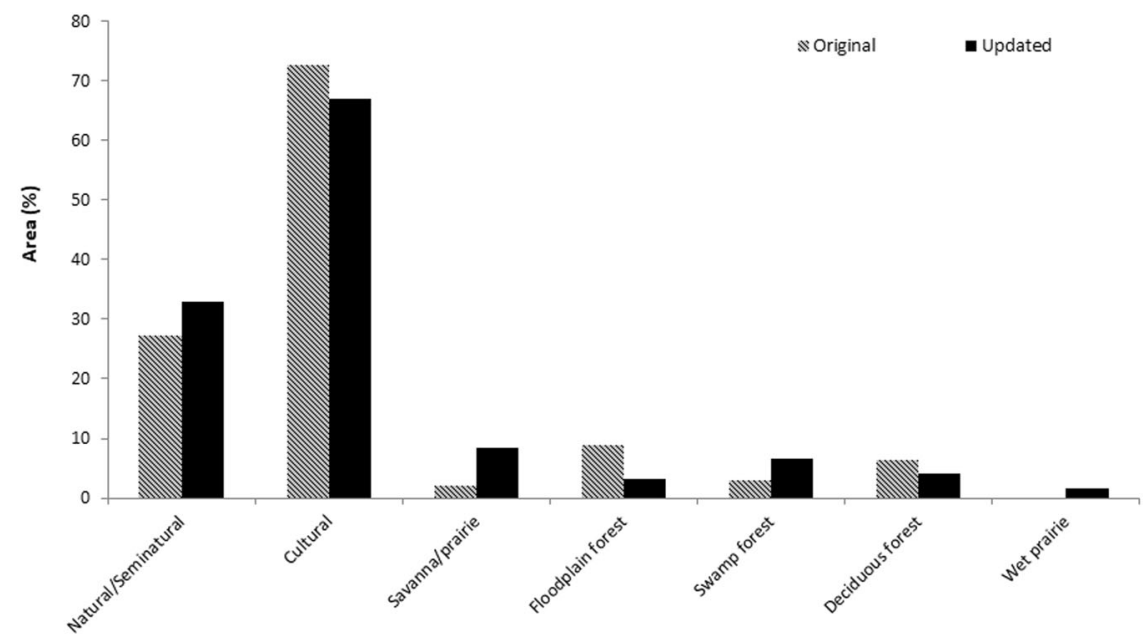

\section{Five major communities of concern}

For the five major communities of concern, we found that both floodplain and deciduous forest decreased in percent area, while swamp forest, savanna/prairie, and wet prairie increased in percent area (Fig. 2). Both floodplain forest and wet prairie decreased in average patch area, while upland savanna/prairie, swamp, and deciduous forest increased. Upland savanna/prairie increased more than 3000 patches and a similar size decreased in number of patches for floodplain forest (Table 2). Overall, the largest patch size increased for all five major communities, except upland deciduous forest. We assessed connectivity (Fig. 3), dispersion (Fig. 4) and heterogeneity (Fig. 5) for each of the 

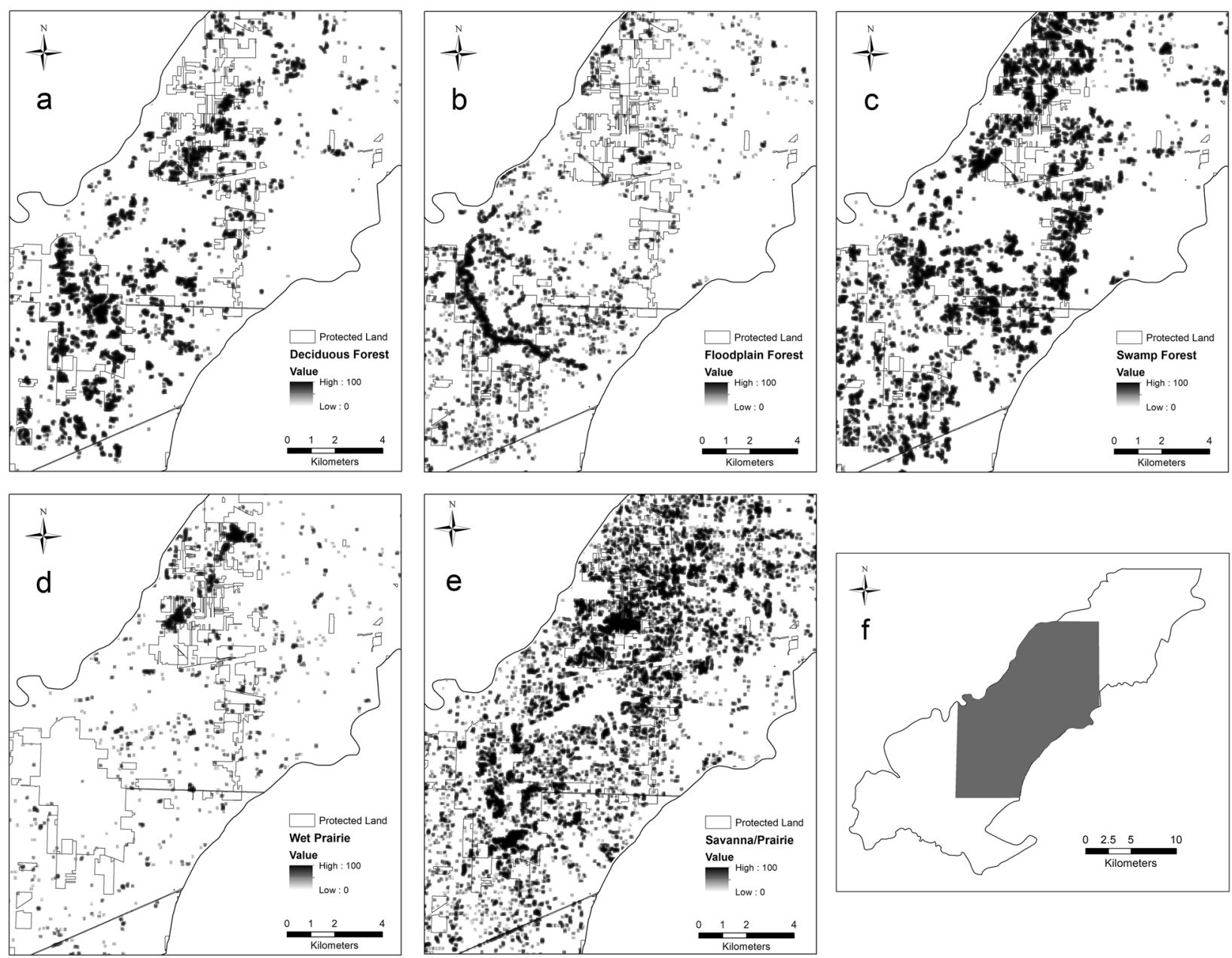

Fig. 3 An estimate of connectivity using COHESION for the five major communities of concern (a-e) in the Ohio portion of Oak Openings (f); approaching 0 (lighter color) represents a physically

five major communities of concern and overall landscape. These trends are illustrated for an example area near the Toledo airport where there are a few protected areas managed by The Metroparks of the Toledo Area and The Nature Conservancy. Cohesion and clumpiness for each of the five major communities of concern varied; however upland savanna/prairie had greater connectedness/aggregation and wet prairie had greater division/disaggregation across the area. We found that the number of patches within a $120 \mathrm{~m} \times 120 \mathrm{~m}$ neighborhood window varied from 1 to 10 land cover classes, where ten represented greater heterogeneity.

\section{Map Accuracy Assessment}

We evaluated 500 field assessable points with groundtruthing and orthophotos to validate the updated map. Our results were compiled in an error matrix (Table 3) and highlighted an overall accuracy of $71.2 \%$ with a kappa (measure of agreement due to chance) of 0.68. Producer's disconnected focal class and approaching 100 (darker color) represents a cohesive aggregated focal class

accuracy ranged from $25 \%$ for turf/pasture to $96.4 \%$ for cropland. User's accuracy ranged from $0 \%$ for Eurasian meadow to $100 \%$ for perennial pond. We examined the seven-level classes and found that overall map accuracy improved to $80.8 \%$ with a kappa of 0.76. Producer's accuracy ranged from $70 \%$ for savanna to $93.2 \%$ for vacant. User's accuracy ranged from $51.2 \%$ for savanna to $100 \%$ for perennial pond.

\section{Protected Areas and Restoration Efforts}

We examined the total of permanently protected areas within Oak Openings Region of Northwest Ohio and found that $12 \%$ of the land is currently in protection with $10 \%$ of natural/seminatural land cover in protection. Our analysis focused on changes over time for the five major communities of concern within protected areas and found that upland savanna/prairie increased by $1 \%$, upland deciduous forest increased by $13 \%$, and floodplain forest increased by $20 \%$, while wet prairie decreased by $35 \%$ and swamp forest 

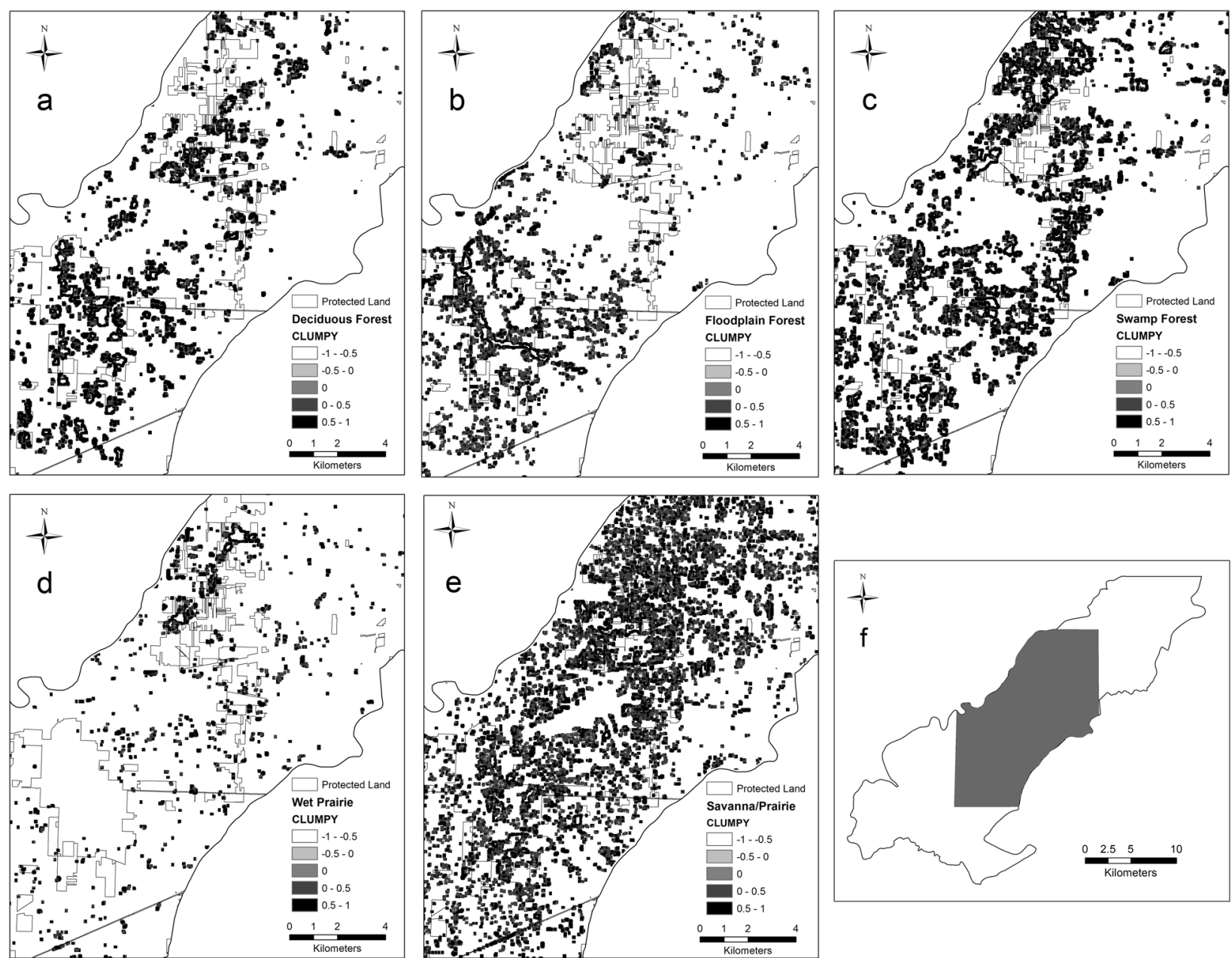

Fig. 4 An estimate of the dispersion using CLUMPY for the five major communities of concern (a-e) in the Ohio portion of Oak Openings (f); patch type; zero represents a random distribution and approaching 1 (darker color) represents maximally aggregated patch type within a approaching -1 (lighter color) represents maximally disaggregated

neighborhood of $120 \times 120 \mathrm{~m}$. Protected lands are outlined in gray

Fig. 5 An estimate of the heterogeneity using patch richness (a) in the Ohio portion of Oak Openings (b); it shows the number of different land cover types (out of 15) that are within a neighborhood of $120 \mathrm{~m} \times 120 \mathrm{~m}$. Values of 1 represent a neighborhood of all the same type of land cover, whereas 10 represent the same size neighborhood with 10 different land cover types
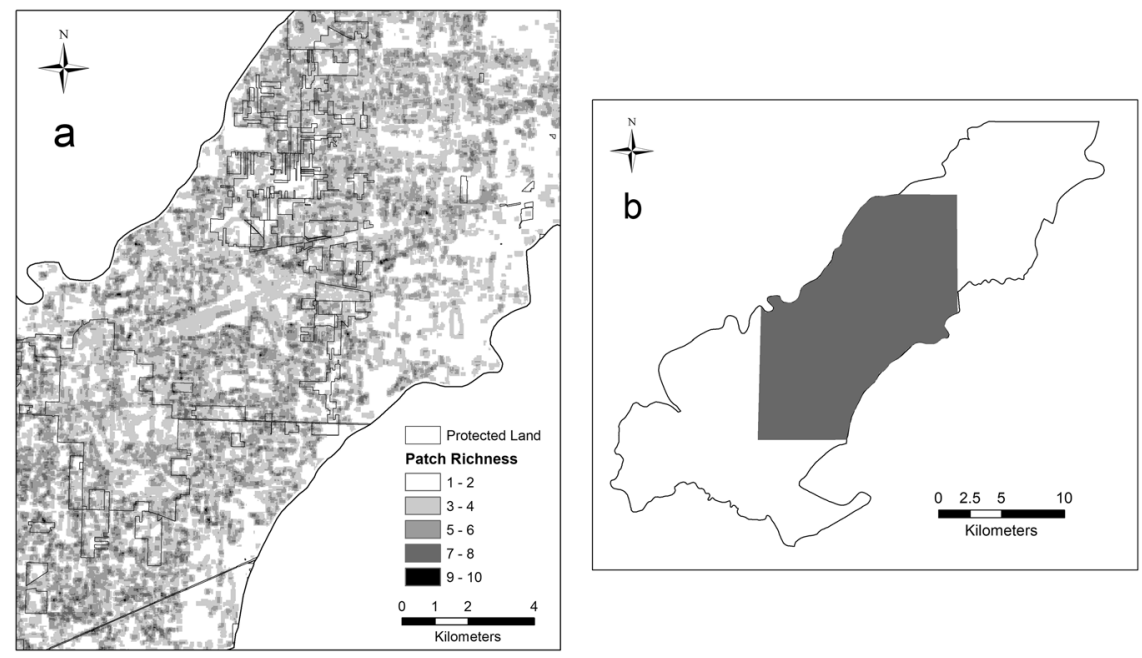

decreased by $6 \%$ over time (Fig. 6). Positive changes within protected areas corresponded with negative changes within unprotected areas; for example, a $20 \%$ increase in protected floodplain forest corresponded with a $20 \%$ decrease in unprotected areas. The patch characteristics within protected areas varied for the five major communities of concern 
Table 3 Error matrix and accuracy for the 15-class oak openings region land cover map

\begin{tabular}{|c|c|c|c|c|c|c|c|c|c|c|c|c|c|c|c|c|c|c|}
\hline & \multicolumn{16}{|c|}{ Actual land cover (reference sites) } & \multirow[t]{2}{*}{ Row total } & \multirow{2}{*}{$\begin{array}{l}\text { User's } \\
\text { accuracy }(\%)\end{array}$} \\
\hline & Class & SF & $\mathrm{FF}$ & UD & $\mathrm{UC}$ & US & WS & WP & UP & SB & EM & $\mathrm{PP}$ & DU & $\mathrm{RM}$ & $\mathrm{TP}$ & $\mathrm{CR}$ & & \\
\hline \multirow{15}{*}{$\begin{array}{l}\text { Classified land } \\
\text { cover (from map) }\end{array}$} & SF & 25 & 1 & 4 & 0 & 0 & 0 & 0 & 0 & 0 & 0 & 0 & 0 & 0 & 0 & 0 & 30 & 83.3 \\
\hline & $\mathrm{FF}$ & 0 & 11 & 8 & 0 & 1 & 0 & 0 & 1 & 0 & 0 & 0 & 0 & 0 & 0 & 2 & 23 & 47.8 \\
\hline & UD & 4 & 0 & 46 & 0 & 1 & 0 & 0 & 0 & 0 & 0 & 0 & 0 & 0 & 0 & 0 & 51 & 90.2 \\
\hline & UC & 0 & 0 & 2 & 38 & 0 & 0 & 0 & 0 & 0 & 0 & 0 & 0 & 0 & 0 & 0 & 40 & 95 \\
\hline & US & 0 & 0 & 19 & 0 & 21 & 0 & 1 & 0 & 0 & 0 & 0 & 0 & 0 & 0 & 0 & 41 & 51.2 \\
\hline & WS & 0 & 0 & 0 & 0 & 0 & 0 & 0 & 0 & 0 & 0 & 0 & 0 & 0 & 0 & 0 & 0 & $\mathrm{n} / \mathrm{a}$ \\
\hline & WP & 0 & 0 & 0 & 0 & 0 & 0 & 4 & 0 & 0 & 0 & 3 & 2 & 0 & 0 & 0 & 9 & 44.4 \\
\hline & UP & 0 & 0 & 6 & 3 & 5 & 0 & 5 & 26 & 1 & 0 & 4 & 0 & 1 & 1 & 0 & 52 & 50 \\
\hline & SB & 0 & 0 & 1 & 1 & 2 & 0 & 0 & 11 & 5 & 0 & 0 & 0 & 2 & 0 & 0 & 22 & 22.7 \\
\hline & EM & 0 & 0 & 0 & 0 & 0 & 0 & 0 & 2 & 0 & 0 & 0 & 4 & 3 & 0 & 0 & 9 & 0 \\
\hline & $\mathrm{PP}$ & 0 & 0 & 0 & 0 & 0 & 0 & 0 & 0 & 0 & 0 & 41 & 0 & 0 & 0 & 0 & 41 & 100 \\
\hline & DU & 0 & 0 & 0 & 0 & 0 & 0 & 0 & 0 & 1 & 0 & 4 & 37 & 0 & 0 & 0 & 42 & 88.1 \\
\hline & $\mathrm{RM}$ & 0 & 0 & 1 & 12 & 0 & 0 & 0 & 3 & 0 & 0 & 3 & 9 & 48 & 1 & 0 & 77 & 62.3 \\
\hline & $\mathrm{TP}$ & 0 & 0 & 0 & 0 & 0 & 0 & 0 & 0 & 3 & 0 & 0 & 0 & 0 & 1 & 0 & 4 & 25 \\
\hline & $\mathrm{CR}$ & 0 & 0 & 0 & 0 & 0 & 0 & 0 & 0 & 0 & 0 & 0 & 4 & 1 & 1 & 53 & 59 & 89.8 \\
\hline Column total & & 29 & 12 & 87 & 54 & 30 & 0 & 10 & 43 & 10 & 0 & 55 & 56 & 55 & 4 & 55 & 500 & \\
\hline \multirow{2}{*}{$\begin{array}{l}\text { Producer's } \\
\text { accuracy }(\%)\end{array}$} & & 86.2 & 91.7 & 52.9 & 70.4 & 70.0 & $\mathrm{n} / \mathrm{a}$ & 40.0 & 60.5 & 50.0 & $\mathrm{n} / \mathrm{a}$ & 74.5 & 66.1 & 87.3 & 25.0 & 96.4 & & \\
\hline & \multicolumn{18}{|c|}{ Карра $=0.68$} \\
\hline \multirow[t]{4}{*}{ Key } & \multicolumn{5}{|c|}{ SF Swamp Forest } & \multicolumn{5}{|c|}{ US Upland Savanna } & \multicolumn{5}{|c|}{$S B$ Sand Barrens } & \multicolumn{3}{|c|}{$R M$ Residential/Mixed } \\
\hline & \multicolumn{5}{|c|}{ FF Floodplain Forest } & \multicolumn{5}{|c|}{ WS Wet Shrubland } & \multicolumn{5}{|c|}{ EM Eurasian Meadows } & \multicolumn{3}{|c|}{$T P$ Turf/Pasture } \\
\hline & \multicolumn{5}{|c|}{$U D$ Upland Deciduous Forest } & \multicolumn{5}{|c|}{$W P$ Wet Prairie } & \multicolumn{5}{|c|}{$P P$ Perennial Ponds } & \multicolumn{3}{|c|}{$C R$ Cropland } \\
\hline & \multicolumn{5}{|c|}{$U C$ Upland Coniferous Forest } & \multicolumn{5}{|c|}{$U P$ Upland Prairie } & \multicolumn{5}{|c|}{$D U$ Dense Urban } & & & \\
\hline
\end{tabular}

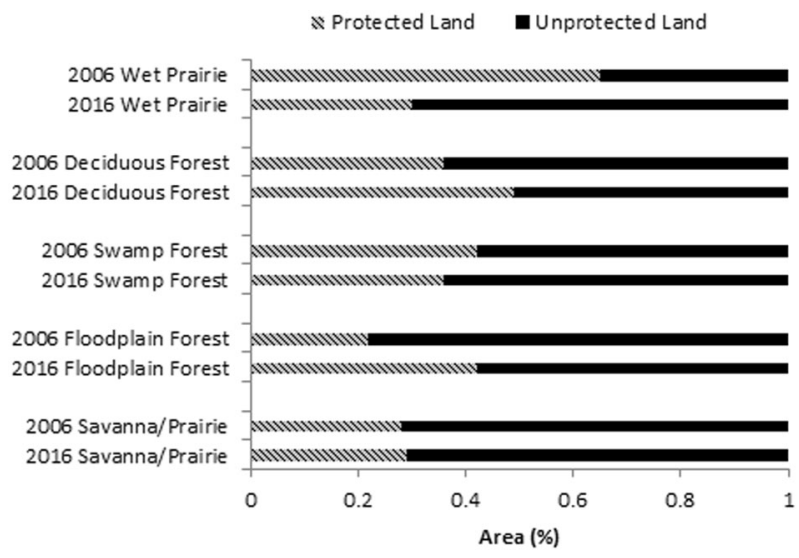

Fig. 6 Summary of percent area for each of the major communities of concern for both protected (pattern) and unprotected (no pattern) lands in the Ohio portion of Oak Openings Region for the original (Schetter and Root 2011) and updated land cover map

(Table 4). Upland savanna/prairie tripled in the number of patches with the average patch area and largest patch size, respectively, increasing by 0.17 ha and $0.4 \%$ over time. We found that upland deciduous forest decreased over time, except in average patch area. Upland deciduous forest lost 221 patches and the largest patch size dropped by $0.55 \%$.
We examined land cover changes within Oak Openings Preserve and found that both upland deciduous and coniferous forest decreased in total area over time, respectively by 64 ha and 161 ha, while floodplain and swamp forest increased in total area over time, respectively by 17 ha and 23 ha. All forest land covers lost a range of 32-176 patches; swamp forest had the largest loss and conifer forest had the smallest loss of patches. As expected from targeted restoration efforts towards dry early successional land cover, we found an increase in total area of 175 ha for upland prairie, 66 ha for upland savanna, and 53 ha for sand barren. Dry early successional land cover all gained a range of 61-216 patches, with upland prairie had the greatest gain and upland savanna had the smallest gain of patches.

\section{Discussion}

\section{Land Cover Maps can Reveal Spatial and Temporal Changes}

Significant changes often occur over time and it is critical to understand these changes when prioritizing land management and conservation in a region (Fardila et al. 2017). 
Table 4 Summary of land cover results for all currently protected parks and preserves in Oak Openings Region for the original (Schetter and Root 2011) and updated land cover maps

\begin{tabular}{|c|c|c|c|c|c|c|c|c|c|c|}
\hline \multirow[b]{2}{*}{ Land cover type } & \multicolumn{2}{|c|}{ \# patches } & \multicolumn{2}{|c|}{ LPI $(\%)$} & \multicolumn{2}{|c|}{$\mathrm{ED}(\mathrm{m} / \mathrm{ha})$} & \multicolumn{2}{|c|}{ AVG area (ha) } & \multicolumn{2}{|c|}{ Cohesion } \\
\hline & 2006 & 2016 & 2006 & 2016 & 2006 & 2016 & 2006 & 2016 & 2006 & 2016 \\
\hline Savanna/Prairie & 452 & 1515 & 0.97 & 1.37 & 30.24 & 99.21 & 0.6 & 0.77 & 82.98 & 86.98 \\
\hline Floodplain Forest & 1465 & 923 & 3.98 & 3.7 & 105.06 & 72.29 & 0.62 & 0.68 & 88.86 & 90.88 \\
\hline Swamp Forest & 1170 & 744 & 0.85 & 1.09 & 83.36 & 16.11 & 0.52 & 1.53 & 81.59 & 88.87 \\
\hline Deciduous Forest & 699 & 478 & 1.6 & 1.05 & 88.18 & 57.18 & 1.53 & 1.95 & 90.51 & 89.8 \\
\hline Wet Prairie & 27 & 361 & 0.2 & 0.73 & 1.96 & 99.21 & 0.94 & 0.57 & 81.56 & 84.24 \\
\hline
\end{tabular}

Italic numbers represent increases over time

$A V G$ average, $N P$ number of patches, LPI largest patch index, ED edge density, COHESION patch cohesion index

Updating the land cover map provided a useful approach to examine larger-scale trends across the region and should be done periodically (e.g., every 10 years). In the original land cover map of Oak Openings Region, much of the land had been converted to human-modified land cover classes (73\%), while $<3 \%$ was covered by upland early successional habitats, such as prairie and savanna (Schetter et al. 2013). We predicted that natural areas, especially for targeted communities, would have increased over time because of restoration and land acquisition efforts. Our new land cover classification has shown that even though human-modified land cover classes have increased to $76.6 \%$, early successional habitats have also increased to 7\%. This increase in early successional habitats (e.g., increasing wet prairie $(0.1$ to $0.3 \%)$ and upland prairie $(1.3$ to $3.6 \%$ ) is likely a result of the work of the GRI to increase the amount of protected lands and promote ecological conservation through restoration and enhancement of critical natural areas (Abella et al. 2007). For example, the conifer management plan focused on improving timber stands and completely removing conifers in specific locations to convert to native oak woodlands, savannas, and prairies (Metroparks Toledo 2020). This has been effective for benefitting native species and restoring native communities for at least 14 years with a focus on converting pine plantations into savannas and prairies (Abella et al. 2017). Since 2002, 140.8 ha of pine remain after the 2018-2019 management plan and 187.8 ha successfully restored to prairie and savanna (Schetter and Gallaher 2019). The desire to restore open-structure habitat is likely why we found a larger increase in savanna/prairie, while we found a decrease in forest land covers. However, not all changes may be from human modifications, such that natural recovery or disturbances also play a role in restructuring land cover. For example, land managers had a rare opportunity to examine how a natural disturbance can influence restoration efforts from a tornado that hit a 23-year old restoration site in 2010 (Abella et al. 2018). Although the restoration is occurring at specific local sites, the changes detectable at the regional scale provide a view of the larger impacts the collective efforts have had on the overall landscape (Fig. 7).

The efforts to protect and restore early successional habitat have been successful, as demonstrated by an increase in habitat cover by $11 \%$; however, other changes were not as favorable. The updated land cover map also revealed declines in vacant $(-7.6 \%)$ and forest and woodland $(-5.4 \%)$ land cover. The loss of forest is not surprising given factors such as the rise of invasive species (e.g., Emerald Ash Borer, Gypsy Moth, Lymantria dispar, Linnaeus), disease (e.g., oak wilt, Ceratocystis fagacearum) and continuing development and fragmentation in the region. Deforestation is already widespread from direct loss and expanding anthropogenic land cover; however, remnant forests are additionally suffering from changes in structural characteristics such as more isolation, smaller size, and greater area of edge habitat (Haddad et al. 2015). Additional structural changes occur from both of the invasive species that have led to large mortality rates and defoliation of both ash (Fraxinus spp.) and oak (Quercus spp.) trees, resulting in a loss of area and connectivity among forest habitat (Knight et al. 2013; Domínguez-Begines et al. 2018). Although some of these species invaded Northwest Ohio before our original land cover map, we are now detecting the long-term consequences. Invasive species can have a secondary release into the surrounding natural landscapes from their established focal sources in urban areas (Alston and Richardson 2006; von der Lippe and Kowarik 2008). Therefore, the growing development and fragmentation in this region may increase the susceptibility of this biodiverse region to invasive species and other threats.

\section{Improvements in the Land Cover Mapping}

Oak Openings Region is a biodiversity hotspot characterized by its highly heterogeneous landscape, making it an excellent model to assess mapping accuracy. Overall, our map accuracy was $73.8 \%$, which was an improvement over 
Fig. 7 Enlarged area of the original 2006 (a) (Schetter and Root 2011) and updated 2016 (b) land cover map within Oak Openings Preserve where pine removal occurred by land managers in 2010

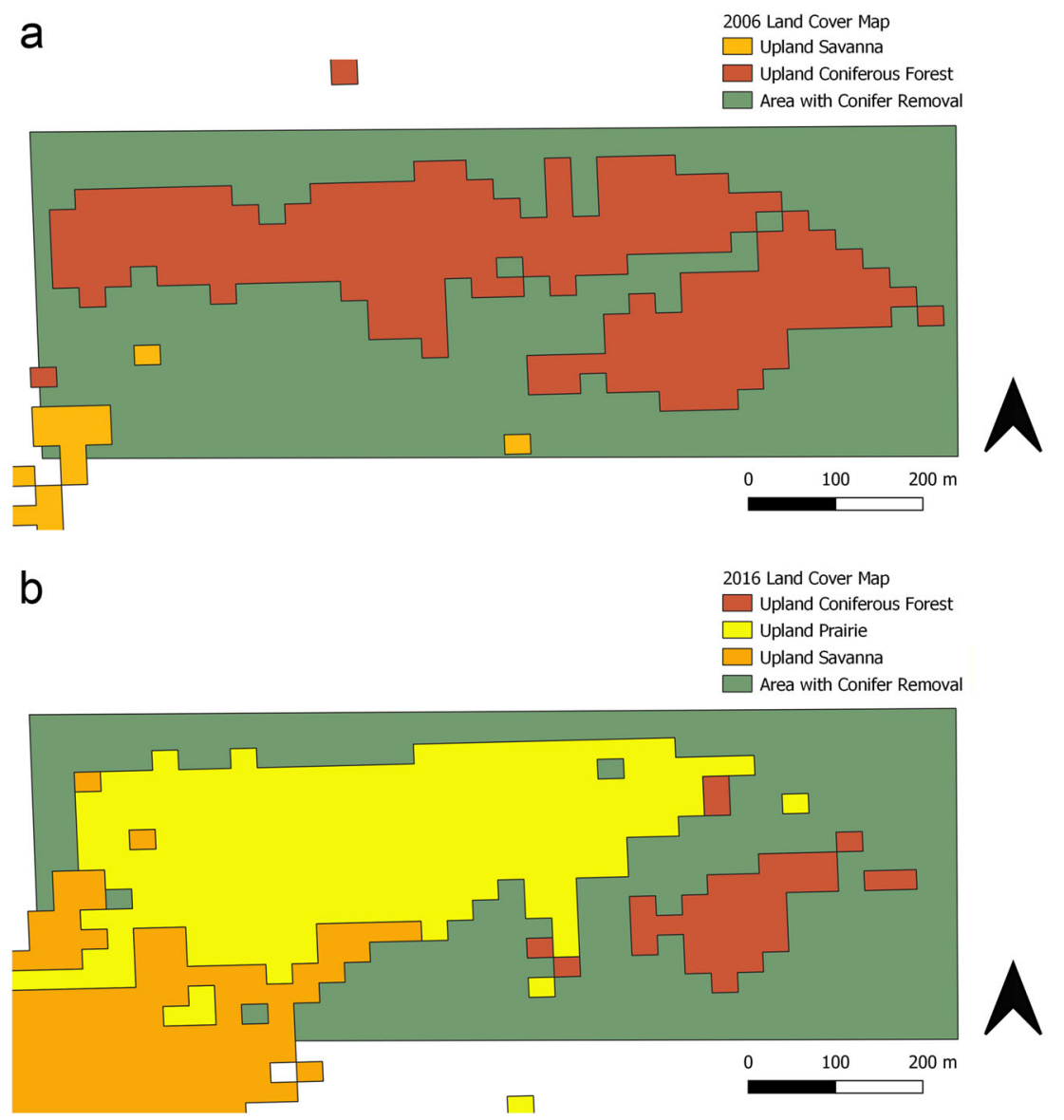

the $60 \%$ accuracy of the original land cover map. The improved accuracy is likely a result of the additional spectral data available in Landsat 8 images versus Landsat 5 (Poursanidis et al. 2015). However, we verified only a selection of the land cover classes as a result of time constraints. These selected land covers may be easier to detect, such as perennial pond and upland coniferous forest, and may not represent the accuracy for all land cover classes. Some caution is warranted, therefore, in the absence of further verification. For some classes, such as upland conifer, we were highly successful in accurately matching the satellite image to the real world. Whereas our map poorly predicts wet prairie based on the ground truth points, which were primarily upland prairie. We found a decrease of $35 \%$ over time for wet prairie within protected lands, despite corroborated wet prairie restoration which occurred over the last decade. This could be a result of overclassifying wet prairie across unprotected lands and we suggest increasing training data for this land cover class across the region. The original training data provided a reasonable classification, but some classes were too broad and overlapped with other land cover classes. With additional training points, the classification can be improved providing a more accurate map. In addition, technological advancements may increase accurate mapping with the release of newer Landsat data within the next 10 years. Our recommendation would be to identify additional training points within land cover classes of concern based on conservation and management goals for the region of interest.

\section{Complementary Approaches can Increase Understanding of Changes}

One unique aspect of our study is the incorporation of changes in landscape configuration as a measure of functionality, which is often underutilized when examining restoration efforts. Therefore, in addition to changes in the amount of habitat, how it is distributed has also changed. These changes are readily visible when we simplified the land cover map to highlight the seven-level class map, as seen in Fig. 8. The results of our fragmentation analysis suggest that the number of patches is increasing, particularly for specific land cover classes (e.g., upland prairie, wet prairie). While the overall proportion of some of these land cover classes has increased, the distribution is one of small isolated patches, which are likely to be far more vulnerable to further degradation and invasion. Although 


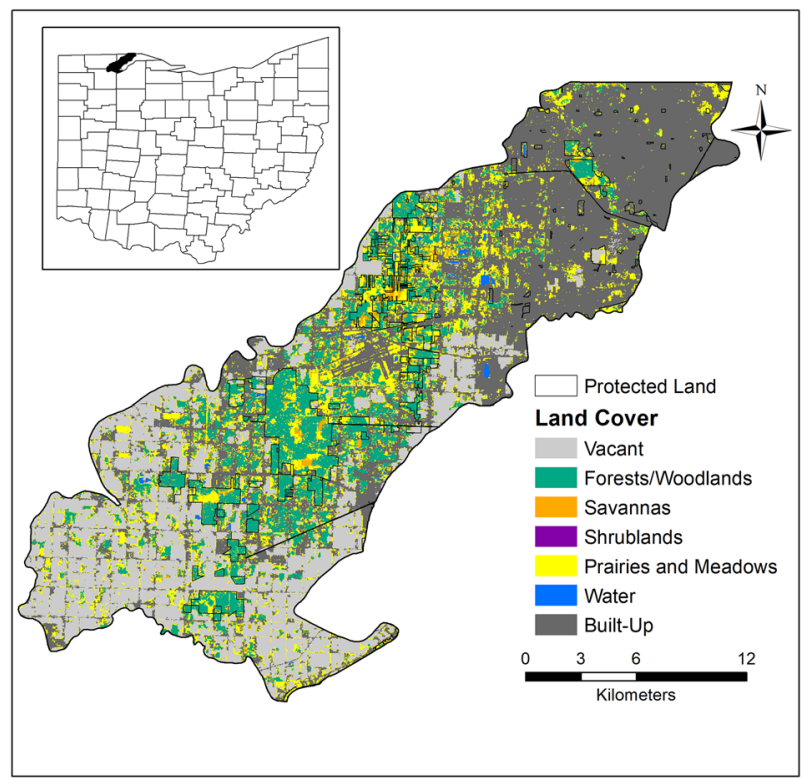

Fig. 8 Simplified 7-class land cover map for the Northwest Ohio portion of Oak Openings Region. Protected land outlined in black

habitat configuration is more important when levels are below $10-30 \%$, it is important to incorporate these changes within management plans and create threshold tests for ecological processes and species (Homan et al. 2004). Like our study, others have found increased fragmentation (Hanberry and Abrams 2018) and a complex pattern of fragmentation (Fardila et al. 2017) across the landscape over time. Conservation targets that examine the pattern, as well as the amount of habitat, can help counter the piecemeal restoration that typically occurs in humanmodified landscapes, therefore managing the entire mosaic rather than individual pieces (Lindenmayer et al. 2008). With many of the protected areas in this region surrounded by anthropogenic features, it would be beneficial to focus on increasing patch size to buffer the impacts of anthropogenic factors. The surrounding matrix often has large influences on populations and communities often much more than processes within remnant focal patches (Wiens 1995), and many species responses are often scaledependent (Turner et al. 2001). This approach provides a way to prioritize connectivity efforts to offset increasing fragmentation and fosters planning at larger scales, which has been recommended by others (e.g., Fardila et al. 2017; Watson et al. 2017).

While the land cover and fragmentation analysis can reveal the changes within the landscape, it is limited to vegetation or structural characteristics. The goal for conservation is healthy functional ecosystems, which requires an assessment of quality as well as quantity. We can address this need by combining land cover data with target indicator species to identify habitat quality rather than just habitat quantity. For example, species distribution models were developed for the red-backed salamander (Plethodon cinereus, Green) using occurrence data, land cover, and soil maps. Red-backed salamanders are widely distributed among upland deciduous forest with population densities reaching up to 0.9-2.2 individuals $/ \mathrm{m}^{2}$ (Pough et al. 1987). They are found preferably under deciduous leaf litter over coniferous forest (Renaldo et al. 2011) and represent an excellent model for examining habitat functionality. The resulting model highlights functional upland deciduous forest from the perspective of a native occupant and identifies important habitat in terms of both area and function. This type of species distribution model presents other landscape features that provide additional support for native species, such as floodplain forest and specific soil types. Complementary approaches such as occupancy modeling in conjunction with land cover maps aid in conservation planning of both quality and quantity of functional native ecosystems.

\section{Conclusions}

The study explored the effects of the ground management on LULC over a 10-year period in Oak Openings Region. We found positive changes for the two early successional communities which were key land management targets. This suggests that local scale (i.e., on the ground changes) from local land managers can be visible from landscape viewpoints (i.e., satellite data) over time. Land managers would benefit from examining regional maps for overall long-term conservation plans to preserve a variety of natural habitats to maintain the natural biodiversity and ecosystem function. Not only is this approach valuable to evaluate the larger scale impacts of small-scale restoration projects, but it also highlights critical features (e.g., connectivity) that can identify priorities for future acquisition and conservation and targets for management activities. Our results illustrate the challenges that land managers face, in that focused restoration can help some facets of the landscape, but degradation and fragmentation are likely to continue as human-modified land covers expand and/or encroach on natural habitats. Project-by-project approach may not be as effective in mitigating these negative effects, therefore there is a need to have a comprehensive large-scale view of conservation planning to effectively mitigate future changes.

Acknowledgements This project was made possible through support provided by the U.S. Fish and Wildlife Service, the Ohio Department of Natural Resources and The Nature Conservancy, under the terms of grant Agreement \#F15AF00519. The content and opinions expressed herein are those of the author(s) and do not necessarily reflect the position or the policy of such agency or The Nature Conservancy, and 
no official endorsement should be inferred. We thank Timothy Schetter, Steven Woods, and Julia Gehring for their contributions to the project. We additionally thank both Timothy Schetter and Rachel Kappler for constructive feedback and for reviewing the manuscript.

Author Contributions Conceptualization: KVR; Methodology: AKM and KVR; Formal analysis and investigation: AKM; Writing-original draft preparation: AKM; Writing-review and editing: AKM and KVR; Resources: KVR; Supervision: KVR. All authors have read and approved the final manuscript.

Funding This project was made possible through support provided by the U.S. Fish and Wildlife Service, the Ohio Department of Natural Resources and The Nature Conservancy, under the terms of grant Agreement \#F15AF00519.

\section{Compliance with Ethical Standards}

Conflict of Interest The authors declare that they have no conflict of interest.

Publisher's note Springer Nature remains neutral with regard to jurisdictional claims in published maps and institutional affiliations.

Open Access This article is licensed under a Creative Commons Attribution 4.0 International License, which permits use, sharing, adaptation, distribution and reproduction in any medium or format, as long as you give appropriate credit to the original author(s) and the source, provide a link to the Creative Commons license, and indicate if changes were made. The images or other third party material in this article are included in the article's Creative Commons license, unless indicated otherwise in a credit line to the material. If material is not included in the article's Creative Commons license and your intended use is not permitted by statutory regulation or exceeds the permitted use, you will need to obtain permission directly from the copyright holder. To view a copy of this license, visit http://creativecommons. org/licenses/by/4.0/.

\section{References}

Abella SR, Jaeger JF, Schetter TA(2007) Public land acquisition and ecological restoration: an example from northwest Ohio's Oak Openings Region. Nat Areas J 27:92-97. https://doi.org/10.3375/ 0885-8608(2007)27[92:PLAAER]2.0.CO;2

Abella SR, Schetter TA, Walters TL (2017) Restoring and conserving rare native ecosystems: a 14-year plantation removal experiment. Biol Conserv 212:265-273. https://doi.org/10.1016/j.biocon. 2017.06.034

Abella SR, Schetter TA, Jaeger JF, Brewer L, Menard KS, Gallaher TD, Diver JJ, Sprow LA (2018) Resistance and resilience to natural disturbance during ecological restoration. Ecol Restor 36:284-294. https://doi.org/10.3368/er.36.4.284

Alston KP, Richardson DM (2006) The roles of habitat features, disturbance, and distance from putative source populations in structuring alien plant invasions at the urban/wildland interface on the Cape Peninsula, South Africa. Biol Conserv 132:183-198. https://doi.org/10.1016/j.biocon.2006.03.023

Bell SS, Fonseca MS, Motten LB (1997) Linking restoration and landscape ecology. Restor Ecol 5:318-323. https://doi.org/10. 1046/j.1526-100X.1997.00545.x

Brewer LG, Vankat JL (2004) Description of vegetation of the Oak Openings of northwestern Ohio at the time of Euro-American settlement. Ohio J Sci 104:76-85
Clark ML, Buck-Diaz J, Evens J (2018) Mapping of forest alliances with simulated multi-seasonal hyperspectral satellite imagery. Remote Sens Environ 210:490-507. https://doi.org/10.1016/j.rse. 2018.03.021

Cordell S, Questad EJ, Asner GP, Kinney KM, Thaxton JM, Uowolo A, Brooks S, Chynoweth MW (2016) Remote sensing for restoration planning: how the big picture can inform stakeholders. Restor Ecol 25:S147-S154. https://doi.org/10.1111/rec.12448

Domínguez-Begines J, De Deyn GB, García LV, Eisenhauer N, Gómez-Aparicio L (2018) Cascading spatial and trophic impacts of oak decline on the soil food web. J Ecol 107:1199-1214. https://doi.org/10.1111/1365-2745.13091

Driezen K, Adriaensen F, Rondinini C, Doncaster CP, Matthysen E (2007) Evaluating least-cost model predictions with empirical dispersal data: a case-study using radiotracking data of hedgehogs (Erinaceus europaeus). Ecol Model 209:314-322. https://doi.org/ 10.1016/j.ecolmodel.2007.07.002

Dusseux P, Corpetti T, Hubert-Moy L, Corgne S (2014) Combined use of multi-temporal optical and radar satellite images for grassland monitoring. Remote Sens 6:6163-6182. https://doi.org/10.3390/ rs6076163

Ehrenfeld JG, Toth LA (1997) Restoration ecology and the ecosystem perspective. Restor Ecol 5:307-317. https://doi.org/10.1046/j. 1526-100X.1997.00544.X

El Baroudy AA, Moghanm FS (2014) Combined use of remote sensing and GIS for degradation risk assessment in some soils of the Northern Nile Delta, Egypt. Egypt J Remote Sens Space Sci 17:77-85. https://doi.org/10.1016/j.ejrs.2014.01.001

Eldridge DJ, Bowker MA, Maestre FT, Roger E, Reynolds JF, Whitford WG (2011) Impacts of shrub encroachment on ecosystem structure and functioning: towards a global synthesis. Ecol Lett 14:709-722. https://doi.org/10.1111/j.1461-0248. 2011.01630.x

Fahrig L (2003) Effects of habitat fragmentation on biodiversity. Ann Rev Ecol Evol Syst 34:487-515. https://doi.org/10.1146/annurev. ecolsys.34.011802.132419

Fahrig L, Baudry J, Brotons L, Burel FG, Crist TO, Fuller RJ, Sirami C, Siriwardena GM, Martin J (2011) Functional landscape heterogeneity and animal biodiversity in agricultural landscapes. Ecol Lett 14:101-112. https://doi.org/10.1111/j.1461-0248.2010. 01559.x

Fardila D, Kelly LT, Moore JL, McCarthy MA (2017) A systematic review reveals changes in where and how we have studied habitat loss and fragmentation over 20 years. Biol Conserv 212:130-138. https://doi.org/10.1016/j.biocon.2017.04.031

Gardner R (2016) Plant communities of the Oak Openings. In: Weber A, Fisher T, Gardner R, Walters T, Tramer E, Jacksy B, Bekker K, Lipps G, Parshall DK, Bradley R, Grigore M, Woods S, Thieme J (ed) Living in the Oak Openings: a Guide to one of the world's last great places, 3rd edn. Toledo, Ohio, p 10-15

Gottgens JF, Swartz BP, Kroll RW, Eboch M (1998) Long-term GIS-based records of habitat changes in a Lake Erie coastal marsh. Wetl Ecol Manag 6:5-17. https://doi.org/10.1023/A: 1008439519760

Gudex-Cross D, Pontius J, Adams A (2017) Enhanced forest cover mapping using spectral unmixing and object-based classification of multi-temporal Landsat imagery. Remote Sens Environ 196:193-204. https://doi.org/10.1016/j.rse.2017.05.006

Haddad NM, Brudvig LA, Clobert J, Davies KF, Gonzalez A, Holt RD, Lovejoy TE, Sexton JO, Austin MP, Collins CD, Cook WM, Damschen EI, Ewers RM, Foster BL, Jenkins CN, King AJ, Laurance WF, Levey DJ, Margules CR, Melbourne BA, Nicholls AO, Orrock JL, Song D, Townshend JR (2015) Habitat fragmentation and its lasting impact on Earth's ecosystems. Sci Adv 1:e1500052. https://doi.org/10.1126/sciadv.1500052 
Hanberry BB, Abrams MD (2018) Recognizing loss of open forest ecosystems by tree densification and land use intensification in the Midwestern USA. Reg Environ Change 18:1731-1740. https://doi.org/10.1007/s10113-018-1299-5

Herms DA, McCullough DG (2014) Emerald ash borer invasion of North America: history, biology, ecology, impacts, and management. Ann Rev Entomol 59:13-30. https://doi.org/10.1146/a nnurev-ento-011613-162051

Herse MR, With KA, Boyle WA (2018) The importance of core habitat for a threatened species in changing landscapes. J Appl Ecol 55:2241-2252. https://doi.org/10.1111/1365-2664.13234

Higginbottom TP, Symeonakis E, Meyer H, van der Linden S (2018) Mapping fractional woody cover in semi-arid savannahs using multi-seasonal composites from Landsat data. ISPRS J Photogramm Remote Sens 139:88-102. https://doi.org/10.1016/j. isprsiprs.2018.02.010

Homan RN, Windmiller BS, Reed JM (2004) Critical thresholds associated with habitat loss for two vernal pool-breeding amphibians. Ecol Appl 14:1547-1553

Houlahan JE, Findlay CS (2004) Estimating the 'critical' distance at which adjacent land-use degrades wetland water and sediment quality. Landsc Ecol 19:677-690. https://doi.org/10.1023/B: LAND.0000042912.87067.35

Johnston S, Rejmánková E (2005) Impacts of land use on nutrient distribution and vegetation composition of freshwater wetlands in northern Belize Wetlands 25:89-100. https://doi.org/10.1672/ 0277-5212(2005)025[0089:IOLUON]2.0.CO;2

Kashian DM, Witter JA (2011) Assessing the potential for ash canopy tree replacement via current regeneration following emerald ash borer-caused mortality on southeastern Michigan landscapes. For Ecol Manag 261:480-488. https://doi.org/10.1016/j.foreco.2010. 10.033

Knight KS, Brown JP, Long RP (2013) Factors affecting the survival of ash (Fraxinus spp.) trees infested by emerald ash borer (Agrilus planipennis). Biol Invasions 15:371-383. https://doi.org/ 10.1007/s10530-012-0292-Z

Lindenmayer D, Hobbs RJ, Montague-Drake R, Alexandra J, Bennett A, Burgman M, Cale P, Calhoun A, Cramer V, Cullen P, Driscoll D, Fahrig L, Fischer J, Franklin J, Haila Y, Hunter M, Gibbons P, Lake S, Luck G, MacGregor C, McIntyre S, Mac Nally R, Manning A, Miller J, Mooney H, Noss R, Possingham H, Saunders D, Schmiegelow F, Scott M, Simberloff D, Sisk T, Tabor G, Walker B, Wiens J, Woinarski J, Zavaleta E (2008) A checklist for ecological management of landscapes for conservation. Ecol Lett 11:78-91. https://doi.org/10.1111/j.14610248.2007.01114.x

Liu Q, Song H, Liu G, Huang C, Li H (2019) Evaluating the potential of multi-seasonal CBERS-04 imagery for mapping the quasi-circular vegetation patches in the yellow river delta using random forest. Remote Sens 11:1-24. https://doi.org/10.3390/ rs 11101216

Lopez RD, Davis CB, Fennessy MS (2002) Ecological relationships between landscape change and plant guilds in depressional wetlands. Landsc Ecol 17:43-46. https://doi.org/10.1023/A: 1015203802047

Lovell ST, Johnston DM (2009) Creating multifunctional landscapes: how can the field of ecology inform the design of the landscape? Front Ecol Environ 7:212-220. https://doi.org/10.1890/070178

Löw F, Conrad C, Michel U (2015) Decision fusion and nonparametric classifiers for land use mapping using multi-temporal RapidEye data. ISPRS J Photogramm Remote Sens 108:191-204. https://doi.org/10.1016/j.isprsjprs.2015.07.001

Matzek V, Gornish ES, Hulvey KB (2017) Emerging approaches to successful ecological restoration: five imperatives to guide innovation. Restor Ecol 25:S110-S113. https://doi.org/10.1111/ rec. 12630
McGarigal K, Marks BJ (1995) FRAGSTATS: spatial pattern analysis program for quantifying landscape structure. USDA Forest Service General Technician Report PNWGTR-351, USDA Forest Service, Pacific Northwest Research Station, Portland, OR

Metroparks Toledo (2020) Pine Plantation Management. Metroparks Toledo. https://metroparkstoledo.com/natural-wonders/restora tion/pine-plantation-management. Accessed 7 May 2020

Murphy DD, Noon BR (1992) Integrating scientific methods with habitat conservation planning-reserve design for northern spotted owls. Ecol Appl 2:3-17. https://doi.org/10.2307/1941885

Nitze I, Barrett B, Cawkwell F (2015) Temporal optimisation of image acquisition for land cover classification with Random Forest and MODIS time-series. Int J Appl Earth Obs 34:136-146. https:// doi.org/10.1016/j.jag.2014.08.001

O'Farrell PJ, Anderson PML (2010) Sustainable multifunctional landscapes: a review to implementation. Curr Opin Env Sust 2:59-65. https://doi.org/10.1016/j.cosust.2010.02.005

Peterson DW, Reich PB (2001) Prescribed fire in oak savanna: fire frequency effects on stand structure and dynamics Ecol Appl 11:914-927. https://doi.org/10.1890/1051-0761(2001)011[0914: PFIOSF]2.0.CO;2

Phillips SJ, Anderson RP, Schapire RE (2006) Maximum entropy modeling of species geographic distributions. Ecol Model 190:231-259. https://doi.org/10.1016/j.ecolmodel.2005.03.026

Pickens B, Root KV (2008) Factors affecting host-plant quality and nectar use for the Karner blue butterfly: implications for oak savanna restoration Nat Areas J 28:210-217. https://doi.org/10. 3375/0885-8608(2008)28[210:FAHQAN]2.0.CO;2

Pickens B, Root KV (2009) Butterfly behavior as a tool for assessing a managed landscape: a case study of the Karner blue butterfly. Landsc Ecol 24:243-251. https://doi.org/10.1007/s10980-0089302-z

Pough FH, Smith EM, Rhodes DH, Collazo A (1987) The abundance of salamanders in forest stands with different histories of disturbance. For Ecol Manag 20:1-9. https://doi.org/10.1016/03781127(87)90146-0

Poulin B, Davranche A, Lefebvre G (2010) Ecological assessment of Phragmites australis wetlands using multi-season SPOT5 scenes. Remote Sens Environ 114:1602-1609. https://doi.org/ 10.1016/j.rse.2010.02.014

Poursanidis D, Chrysoulakis N, Mitraka Z (2015) Landsat 8 vs. Landsat 5: a comparison based on urban and peri-urban land cover mapping. Int J Appl Earth Obs 35:259-269. https://doi.org/ 10.1016/j.jag.2014.09.010

Renaldo KA, Murch CW, Riley J, Helleman B, Smith GR, Rettig JE (2011) Substrate preference of eastern red-backed salamanders, Plethodon cinereus: a comparison of deciduous and coniferous substrates. Amphib-Reptilia 32:266-269. https://doi.org/10.1163/ 017353710X550913

Sala OE, Chapin III FS, Armesto JJ, Berlow E, Bloomfield J, Dirzo R, Huber-Sanwald E, Huenneke LF, Jackson RB, Kinzig A, Leemans R, Lodge DM, Mooney HA, Oesterheld M, Poff NL, Sykes MT, Walker BH, Walker M, Wall DH (2000) Global Biodiversity Scenarios for the Year 2100. Science 287:1770-1774. https://doi. org/10.1126/science. 287.5459 .1770

Schetter TA, Gallaher T (2019) Pine management in oak openings preserve. Metroparks Toledo. https://metroparkstoledo.com/ media/4143/pine-management-research-forum-2-9-2019.pdf. Accessed 7 May 2020

Schetter TA, Root KV (2011) Assessing an imperiled oak savanna landscape in northwestern Ohio using Landsat data. Nat Areas J 31:118-130. https://doi.org/10.3375/043.031.0204

Schetter TA, Walters TL, Root KV (2013) A multi-scale spatial analysis of native and exotic plant species richness within a mixeddisturbance oak savanna landscape. Environ Manag 52:581-594. https://doi.org/10.1007/s00267-013-0120-y. 
Srivastava PK, Han D, Rico-Ramirez MA, Bray M, Islam T (2012) Selection of classification techniques for land use/land cover change investigation. Adv Space Res 50:1250-1265. https://doi. org/10.1016/j.asr.2012.06.032

Torbick NM, Qi J, Roloff GJ, Stevenson RJ (2006) Investigating impacts of land-use land cover change on wetlands in the Muskegon river watershed, Michigan, USA Wetlands 26:1103-1113. https://doi.org/10.1672/0277-5212(2006)26[1103: IIOLLC]2.0.CO;2

Tscharntke T, Tylianakis JM, Rand TA, Didham RK, Fahrig L, Batáry $\mathrm{P}$, Bengtsson J, Clough Y, Crist TO, Dormann CF, Ewers RM, Fründ J, Holt RD, Holzschuh A, Klein AM, Kleijn D, Kremen C, Landis DA, Laurance W, Lindenmayer D, Scherber C, Sodhi N, Steffan-Dewenter I, Thies C, van der Putten WH, Westphal C (2012) Landscape moderation of biodiversity patterns and processes-eight hypotheses. Biol Rev 87:661-685. https://doi. org/10.1111/j.1469-185X.2011.00216.x

Turner MG, Gardner RH, O'Neill RV (2001) Landscape ecology in theory and practice: pattern and process. Springer, New York, NY

[USDA] United States Department of Agriculture (2016) National Agricultural Statistics Service Ohio and Michigan Cropland Data Layer. USDA. U.S. Department of Agriculture, Washington, DC. https://datagateway.nrcs.usda.gov/. Accessed 3 Apr 2017

[USGS] United States Geological Survey (2017) USGS Earth Explorer. USGS. U.S. Geological Survey, Reston, VA. https://ea rthexplorer.usgs.gov. Accessed 20 Mar 2017

Villard MA, Trzcinski MK, Merriam G (1999) Fragmentation effects on forest birds: relative influence of woodland cover and configuration on landscape occupancy. Conserv Biol 13:774-783. https://doi.org/10.1046/j.1523-1739.1999.98059.x

von der Lippe M, Kowarik I (2008) Do cities export biodiversity? Traffic as dispersal vector across urban-rural gradients. Divers
Distrib 14:18-25. https://doi.org/10.1111/j.1472-4642.2007. 00401.x

Wang C, Jamison BE, Spicci AA (2010) Trajectory-based warm season grassland mapping in Missouri prairies with multitemporal ASTER imagery. Remote Sens Environ 114:531-539. https://doi.org/10.1016/j.rse.2009.10.010

Watson DM, Doerr VAJ, Banks SC, Driscoll DA, van der Ree R, Doerr ED, Sunnucks P (2017) Monitoring ecological consequences of efforts to restore landscape-scale connectivity. Biol Conserv 206:201-209. https://doi.org/10.1016/j.biocon.2016.12. 032

Wiens JA (1995) Habitat fragmentation: island v landscape perspectives on bird conservation. Ibis 137:S97-S104. https://doi.org/10. 1111/j.1474-919X.1995.tb08464.x

Wijayarathne D (2015) Shallow groundwater modeling of the historical Irwin wet prairie in the oak openings of northwest Ohio. Thesis, Bowling Green State University

Wilson D (2007) A comparison of landscape metrics in relation to neotropical migratory bird occurrence in the driftless area of the Upper Mississippi River Basin. Volume 9, Papers in Resource Analysis. Saint Mary's University of Minnesota Central Services Press, Winona, MN, p 20, http://www.gis.smumn.edu. Accessed 8 Jan 2020

Yuan F, Sawaya KE, Loeffelholz BC, Bauer ME (2005) Land cover classification and change analysis of the Twin Cities (Minnesota) Metropolitan Area by multitemporal Landsat remote sensing. Remote Sens Environ 98:317-328. https://doi.org/10.1016/j.rse. 2005.08.006

Zhao Y, Feng D, Yu L, Wang X, Chen Y, Bai Y, Hernández HJ, Galleguillos M, Estades C, Biging GS, Radke JD, Gong P (2016) Detailed dynamic land cover mapping of Chile: accuracy improvement by integrating multi-temporal data. Remote Sens Environ 183:170-185. https://doi.org/10.1016/j.rse.2016.05.016 